\title{
The impact of religiousness on attitudes towards religious others
}

\author{
Franz Höllinger
}

(C) The Author(s) 2020

\begin{abstract}
Based on data from the Austrian Social Survey 2018, this article analyzes to what extent attitudes towards religious others are influenced by one's relationship with religion. Five aspects of religiosity and attitudes to religion are taken into account: church-related religiosity (religious belief and practice), spirituality (engagement with alternative spiritual methods), religious fundamentalism, positive or negative perceptions of the role of religion in society, and religious denomination. The key findings are: engagement with spiritual methods and viewing religion as beneficial for society correlate with positive ratings of religious others. People with fundamentalist religious convictions are less open to religious others. Members of religious minorities in Austria (Protestants, Orthodox Christians and Muslims) have more positive attitudes to religious others than members of the dominant Catholic Church. How members of different world religions are rated depends on whether the religion in question is perceived as undogmatic and peaceful or as fundamentalist and intolerant in the public discourse.
\end{abstract}

Keywords Religion · Religious diversity $\cdot$ Religious others $\cdot$ Interreligious relationships · Austria 


\section{Der Einfluss der Religiosität auf die Bewertung religiöser Diversität}

Zusammenfassung Dieser Artikel untersucht anhand der Ergebnisse des sozialen Survey Österreich 2018, inwieweit Religiosität die Einstellung zu Angehörigen anderer Religionen beeinflusst. Fünf Aspekte der Religiosität bzw. Einstellung zur Religion werden als relevant erachtet: kirchenbezogene Religiosität (religiöser Glaube und Praxis), Spiritualität (Beschäftigung mit alternativen spirituellen Praktiken), religiöser Fundamentalismus, Bewertung der Rolle der Religion in der Gesellschaft und religiöse Konfession. Die wichtigsten Ergebnisse sind: Die Beschäftigung mit spirituellen Praktiken und eine positive Beurteilung der gesellschaftlichen Rolle der Religion gehen mit einer positiven Bewertung religiöser Diversität einher. Personen, die fundamentalistische religiöse Positionen vertreten, sind weniger offen für Andersgläubige. Angehörige religiöser Minderheiten in Österreich (Protestanten, orthodoxe Christen und Muslime) stehen anderen religiösen Gruppen positiver gegenüber als Mitglieder der katholischen Mehrheitskirche. Die Bewertung von Angehörigen anderer Weltreligionen hängt davon ab, inwieweit diese Religionen in der Öffentlichkeit als undogmatisch und tolerant oder als fundamentalistisch und intolerant wahrgenommen werden.

Schlüsselwörter Einstellungen zu Religion · Religiöse Diversität · Interreligiöse Beziehungen · Österreich

\section{Introduction}

Throughout history, the coexistence of different religions within a geographical territory has often been conflictual. In many cases, interreligious conflicts were connected to a power struggle between dominant and marginal segments of the population or between ethnic groups living in the same or in adjacent territories. Interreligious conflicts have occurred all over the world, however, because of the monotheistic claim that there is only one God and only one path to salvation, the tendency towards rejecting other religions may have been stronger in monotheism than among polytheistic or pantheistic religions (Assmann 2009). The relationship between Christians and Jews in Europe has been conflictual from antiquity to the present. Similarly, Christians and Muslims have fought each other for centuries. In the age of the Reformation, conflicts between Catholics and Protestants led to decades of bloody wars (Nexon 2009).

Since the Enlightenment, the idea of religious freedom and tolerance has gained in importance. In the course of the formation of modern democracies, the close ties between the dominant religion and the state were mitigated and the right to freedom of religion was established (Modood and Kastoryano 2006). Today, most European countries have adopted secularist attitudes to religion, i.e. a "normative commitment to neutrality of the state towards religious affairs, necessitating that the state should neither favor, disfavor, promote, nor discourage any particular religious (or nonreligious) belief and viewpoint over another" (Kettell 2019, p. 3). Secularism entails that social life should be based on an "exclusive humanism" (Taylor 2007) which makes 
no reference to religious arguments, and that personal religious commitments are to be kept apart from the public sphere (Brahm Levey 2008). This attitude has found its clearest expression in the French concept of laicité (Christiano 2017). De facto, however, most European states practice a kind of moderate secularism by adopting holidays of the majority religion as public holidays, offering religious education in school, recognizing organized religion as a public good, or even supporting churches in collecting church taxes (Triandafyllidou 2011; Modood and Kastoryano 2006).

The Enlightenment in Europe was not only a driving force for the implementation of religious freedom, it also was the seedbed for a new type of interreligious conflict. The more radical forms of religious critique during the Enlightenment were not directed against a specific kind of religion, but against religion itself. Belief in the existence of divine powers that influence and determine human life was denounced as superstitious wishful thinking, as a way to surrender to an illusory higher authority instead of assuming the responsibility for one's own life (Barnett 2003; Knoblauch 1999). The ideological opposition between opponents and proponents of religion became a major social and cultural divide in Europe until the second half of the 20th century (Clark and Kaiser 2002). With the decline of communism and the development towards more pragmatic forms of socialism, this divide was attenuated, however, even today, anticlerical sentiments and negative attitudes towards religion continue to be widespread. Religious communities are often rejected, especially if they are perceived as dogmatic, fanatical and intolerant, and if their ethical demands and conduct of life conflict with the ethical principles and standard codes of behavior of modern society (e.g. Stolz et al. 2014). Until some decades ago, this applied in particular to sects and cults that were suspected of indoctrinating and manipulating their followers by means of mind control and brainwashing techniques (Singer 2002; Dawson 2006). With the massive influx of migrants belonging to non-Christian religions and whose way of life differs strongly from that of modern Western Europeans, the conflict over religious and cultural tolerance has acquired a new and much bigger scope. During the last decades, this problem has become critical particularly with regard to Islam which many Europeans accuse of promoting fundamentalist religious world views, violence and modes of behavior that are incompatible with the core values of liberal Western democracy (Modood and Kastoryano 2006; Gottschalk and Greenberg 2008; Schneiders 2010; Triandafyllidou 2011).

On the other hand, in the wake of the countercultural movements of the 1960s and 70s new forms of alternative spirituality, health- and self-awareness techniques have emerged and spread throughout the Western world. Many of these methods are derived from the spiritual and healing traditions of oriental religions, or from pagan, shamanic, esoteric and spiritual traditions, including Christian mysticism and Sufism. Since the modern practice of these methods differs strongly from traditional forms of religion, scholars of religion usually do not consider them as religion, but as modern spirituality (Knoblauch 1999; Heelas and Woodhead 2007; Houtman and Aupers 2007; Stolz et al. 2014). Many persons who are engaged in alternative spiritualities distance themselves from traditional religious communities. At the same time, these spiritual seekers have a tendency towards adopting a kind of patchwork spirituality that includes elements of different religious and spiritual traditions (Heelas and 
Woodhead 2007; Bochinger et al. 2009). Consequently, they do not assume that different religions are incompatible with each other, but rather believe that there is a common core of fundamental truths in all religions (Höllinger and Tripold 2012; Stolz et al. 2014).

The question of how people deal with religious diversity has been of particular relevance in the denominational religious system of the United States. Robert Wuthnow distinguishes three types of reactions to the challenges of religious diversity in his country. The first type stems from people who are "exclusive Christians" and who believe that there is only one true religion. To keep their faith pure and to protect themselves from the dangers of other lifeworlds, they spend a large part of their time in their religious "tribe". Some of these groups go out into the "world" to give a testimony of their faith and try to convince others to convert to their religion. This attitude is characteristic of fundamentalist evangelical churches and (Christian and Non-Christian) sectarian communities in the USA. The second type are "inclusive Christians" who belong to a religious community and identify with its religious beliefs, but do not hold that their religion is the only way to God. Accordingly, their private social network is less focused on members of their religious community and for many of them religion is not an important topic in everyday life. (Wuthnow's distinction between "exclusive" and "inclusive Christians" contradicts the assumption that identification with Christianity goes hand in hand with a rejection of religious others, as defended for example by Friedrichs (2014)). The third group in Wuthnow's study comprises the "spiritual shoppers" who deal with different religious, therapeutic and self-awareness practices that are available in the "spiritual marketplace". They believe that all spiritual paths are ultimately based on the same basic religious truth and pursue similar goals (Wuthnow 2005). In contradiction to Wuthnow, Robert Putnam argues that not only the liberal denominations in America, but also most fundamentalist, evangelical Christians are in favor of religious diversity and maintain social contacts with people who belong to other religions. According to him, the strong religious divide in the USA is not an obstacle to religious tolerance, but rather a condition for it (Putnam 2010).

\section{Research questions und hypotheses}

Building on the theoretical considerations and empirical findings presented above, in this article I will investigate to what extent attitudes towards religious others depend on one's own religiosity and one's relationship with religion. As the investigations of Wuthnow (2005) have shown, religiosity can coincide with inclusive as well as with exclusive views on religion, i.e. with acceptance or rejection of religious diversity. The same applies to non-religiosity: non-religiosity can be associated with a positive appraisal of social and religious diversity, but it can also correspond to a general devaluation of religion and religious others. Thus, I expect people's attitudes to religion to be related to their assessment of religious diversity in the following ways:

First, I assume that attitudes towards religious others are related to the secularreligious divide in contemporary Western societies, i.e. to the question of whether 
one has a positive or a negative relationship towards religion and religious people in general.

Hypothesis 1 Religious people, i.e. people who hold religious beliefs, practice religion and are attached to a religion (regardless of what religion it is), should have more sympathy for persons belonging to other religions than nonreligious persons. Vice versa, nonreligious people should have more positive feelings about atheists and nonreligious persons than the religious.

Hypothesis 2 People who have a positive view of the role of religion in society should be more in favor of religious others than people who evaluate the role of religion in society negatively.

I assume that attitudes to religious others also depend on the type of religiosity. Following Wuthnow, two types of religiosity are particularly relevant here: religious fundamentalism and (alternative) spirituality.

Hypothesis 3 People who take fundamentalist religious positions should have more negative attitudes to religious others than people holding liberal religious or nonreligious positions. Since the inclination of respondents to religious fundamentalism was not explicitly investigated in the survey, this hypothesis can be tested only by means of using sexual morals as a proxy-variable for religious fundamentalism.

Hypothesis 4 Spiritual seekers, i.e. persons who practice body-mind-spirit methods that come from different religious and esoteric traditions, should have more favorable attitudes towards religious others, in particular towards Eastern religions (Hinduism and Buddhism), than traditionally religious or nonreligious people; spiritual seekers should also evaluate atheists and nonreligious people more positively than religious people.

Previous studies have shown that the evaluation of religious others in Germany and in other European countries strongly depends on which religion is concerned (Pollack 2014a). A decisive factor for the assessment of religious others seems to be the extent to which a religion is perceived as fundamentalist, intolerant and aggressive or as nonfundamentalist, tolerant and peaceful, and thus as compatible with life in modern Western societies. In the media and in the public discourse in European countries Muslims are often described and classified as fundamentalist and aggressive towards religious others, whereas Buddhism is idealized as a peaceful religion. Thus, my last hypothesis is:

Hypothesis 5 When comparing the four non-Christian world religions asked for in the survey, Muslims will be rated most negatively, while Buddhists will be rated most positively. 


\section{Empirical findings}

The data source for this analysis is the Sozialer Survey Österreich (Austrian Social Survey) 2018, a representative population survey of the resident Austrian population above 18 years of age, with 1200 respondents. This survey includes the International Social Survey Programme 2018 module on "religion" (ISSP-2018). Most of the items used in the analyses of this article come from the ISSP module. In this survey, the issue of acceptance of religious diversity was addressed in two sets of items: a list of items concerning respondent's attitudes to members of different world religions and to atheists or nonbelievers, and two items about interreligious relationships.

The analysis is carried out in two steps: In the first step, descriptive findings regarding the attitudes of the five main groups of religions in Austria (i.e. Catholics, Protestants, Orthodox Christians, Muslims and non-affiliated) to members of different religions (Christians, Muslims, Jews, Hindus and Buddhists) and to interreligious relationships will be presented. In the second step, the impact of different characteristics of respondents' religiosity on the evaluation of religious others (as claimed in hypotheses 1 to 4 ) is analyzed by multiple regressions. To obtain more differentiated results, regressions are calculated first for the evaluation of four specific religious groups (Muslims, Jews, Buddhists, atheists/non-affiliated); in the final set of regressions, the impact of these factors on the evaluation of interreligious relationships and religious others in general is analyzed.

As a background for the following analyses, I will give a brief description of the religious field in Austria. Until the 1970s, more than 90\% of Austrians were Roman Catholics; and a 5\% minority were Lutheran Protestants. Since then, a significant transformation of the religious field has taken place. Both the Catholic and the Lutheran Church have lost a considerable number of their members; weekly church attendance has declined from around $60 \%$ in the post-war period to less than $15 \%$ today, and more than $20 \%$ of the population state that they have no religion (Zulehner and Polak 2009; Höllinger 2013). Parallel to this, the religious landscape of Austria has become more diverse. This change was brought about, first, by successive waves of immigration from Eastern European and Muslim countries. According to current estimates, around $8 \%$ of the resident Austrian population are Muslims, and more than 5\% are affiliated with an Orthodox Church (Goujon et al. 2017). Second, since the 1960s and 1970s new forms of body-mind-spirit exercises as well as health- and self-awareness techniques have become increasingly popular (Höllinger and Tripold 2012). The sample of the SSÖ 2018 reflects the distribution of the native Austrian population by religious affiliation: Around $60 \%$ of the respondents are Catholics, $5 \%$ are Protestants, $28 \%$ are not affiliated to a religion. Migrants from Islamic and Orthodox Christian countries are underrepresented, however (the sample contains only $4 \%$ Muslims and $2.5 \%$ Orthodox Christians). Spirituality was measured in terms of experience with alternative spiritual and holistic methods such as yoga and meditation. The findings show that around $40 \%$ of the sample have some personal experience with such practices (see the explanations at the end of section 3.1). 


\subsection{Measurements and descriptive results}

In the survey, respondents were asked about their attitudes to members of five world religions (Christians, Muslims, Jews, Hindus and Buddhists) and to "atheists or nonbelievers". ${ }^{1}$ Table 1 shows how respondents belonging to the five major religious groups in in Austria-Catholics, Protestants, Orthodox Christians, Muslims and nonaffiliated - evaluate these groups of religious others (the evaluation of Hindus is very similar to the evaluation of Jews; thus, detailed results are omitted for this case).

As we can see in Table 1, a rather high proportion, between $30 \%$ and $60 \%$ depending on the item, chose the neutral answer categories "neither positive nor negative" or "don't know". This may be due to the fact that some world religions are not widespread in Austria and that many respondents do not have any contact with people belonging to these religions. Since the study is based on face-to-face household interviews, neutral answers may also indicate that one does not want to expose one's attitudes to the interviewer.

Obviously, respondents who are affiliated with a specific religion evaluate people belonging to the same world religion more positively than they evaluate people belonging to other religions. This applies both to Christians and Muslims; in a similar way, people who are not affiliated with a religion evaluate atheists and nonbelievers more positively than others. However, Christians and Muslims living in Austria show a distinct difference in attitudes: a considerable proportion of Christians are averse to Muslims, while Muslims seem to have rather positive attitudes to Christians. Since the majority of the respondents are Christians, this religion is by far the best judged. The rank order of the evaluation of the four non-Christian world religions confirms the expectation formulated in hypothesis 5: Buddhists are rated better than the other three religions; the assessment of Muslims is clearly the most negative.

Protestants, Orthodox Christians and, to a minor extent, Muslims give more positive ratings of religious others (Jews, Hindus, Buddhists and non-affiliated) and of Christians in general than Catholics. A plausible explanation for this finding could be that religious minorities in a particular country are more frequently confronted with religious others in their daily life. Moreover, since they are a minority, tolerance of the religious majority towards them is an important concern for them. The combination of these two factors could make them more open towards religious others in general.

In addition to attitudes to different groups of religious others, the evaluation of interreligious relationships was addressed with the following two questions: "Would you accept a person from a different religion marrying a relative of yours?" In the second item, respondents were asked for their opinion on the statement "People who have different religions are not able to get along together well" (see Table 2). In both cases, a clear majority gives positive assessments of interreligious relationships. Muslims and Protestants judge intercultural relationships somewhat more positively than Catholics; Orthodox Christians and non-affiliated are an intermediate position. The high level of acceptance of interreligious marriage among Muslim respondents is surprising. If Muslim migrants were indeed as open to interreligious relationships

\footnotetext{
1 "Atheists or nonbelievers" was used as a combined category in the questionnaire.
} 
Table 1 Attitudes to members of different religions and to atheists or nonbelievers, by religious affiliation (in percent)

\begin{tabular}{|c|c|c|c|}
\hline Attitudes & Positive & Neutral & Negative \\
\hline To Christians & 65 & 31 & 4 \\
\hline By Catholics & 78 & 21 & 1 \\
\hline By Protestants & 65 & 30 & 5 \\
\hline By Orthodox & 87 & 13 & - \\
\hline By Muslims & 60 & 28 & 13 \\
\hline By non-affiliated & 36 & 54 & 9 \\
\hline To Muslims & 22 & 42 & 36 \\
\hline By Catholics & 19 & 43 & 37 \\
\hline By Protestants & 27 & 45 & 28 \\
\hline By Orthodox & 40 & 40 & 20 \\
\hline By Muslims & 77 & 17 & 6 \\
\hline By non-affiliated & 16 & 42 & 41 \\
\hline To Jews & 29 & 56 & 14 \\
\hline By Catholics & 30 & 57 & 13 \\
\hline By Protestants & 35 & 53 & 12 \\
\hline By Orthodox & 47 & 53 & - \\
\hline By Muslims & 38 & 40 & 21 \\
\hline By non-affiliated & 24 & 58 & 18 \\
\hline To Hindus & 29 & 58 & 13 \\
\hline To Buddhists & 38 & 51 & 11 \\
\hline By Catholics & 38 & 51 & 10 \\
\hline By Protestants & 52 & 40 & 8 \\
\hline By Orthodox & 50 & 47 & 3 \\
\hline By Muslims & 38 & 43 & 19 \\
\hline By non-affiliated & 34 & 53 & 13 \\
\hline To Atheists or nonbelievers & 36 & 53 & 11 \\
\hline By Catholics & 29 & 57 & 14 \\
\hline By Protestants & 42 & 47 & 12 \\
\hline By Orthodox & 67 & 27 & 7 \\
\hline By Muslims & 34 & 34 & 32 \\
\hline By non-affiliated & 48 & 51 & 1 \\
\hline
\end{tabular}

Question: What is your personal attitude towards members of the following religious groups? Answer categories: positive $=$ very positive + positive; neutral $=$ neither positive nor negative + don't know; negative $=$ somewhat negative + negative .

Total number of cases: 1185; thereof: 709 Catholics, 60 Protestants; 30 Orthodox, 47 Muslims, 339 nonaffiliated

as they specify in the survey, this should be reflected in their behavior. Studies on cross-national intermarriage in Germany and the Netherlands provide evidence that this is not the case. According to these studies, in both countries around 95\% of the migrants of Turkish origin are married to a person of Turkish descent (which de facto means, to a Muslim), whereas cross-national marriages are significantly more frequent among migrants from other countries (Kalter and Schroedter 2010; Kalmijn 
Table 2 Attitudes towards interreligious relationships, by religious affiliation (in \%)

\begin{tabular}{lllll}
\hline $\begin{array}{l}\text { Would you accept a person from a dif- } \\
\text { ferent religion marrying a relative of } \\
\text { yours? }\end{array}$ & Definitely & Probably & No & Don't know \\
Total & 37 & & & \\
Catholics & 32 & 35 & 22 & 7 \\
Protestants & 40 & 37 & 24 & 7 \\
Orthodox & 30 & 33 & 10 & 3 \\
Muslims & 47 & 23 & 30 & 7 \\
Non-affiliated & 46 & 30 & 18 & 6 \\
People who have different religions do & Strongly & Undecided + don't & Disagree + \\
not get along well together & agree + agree & know & strongly dis- \\
& & & & agree \\
Total & 27 & 22 & & 51 \\
Catholics & 28 & 24 & & 49 \\
Protestants & 17 & 18 & & 65 \\
Orthodox & 33 & 13 & & 63 \\
Muslims & 19 & 13 & & 49 \\
Non-affiliated & 29 & 22 & & 5 \\
\hline
\end{tabular}

Total number of cases: 1185; thereof: 709 Catholics, 60 Protestants; 30 Orthodox, 47 Muslims, 339 nonaffiliated

and van Tubergen 2006). Even if we do not know whether religion or common cultural descent is the key factor in mate choice, and whether Muslim migrants from other countries have a similarly strong preference for ethnic homogamy as the Turks, these findings cast doubt on the willingness of Muslims to have close interreligious relationships. Given this situation, I assume that the responses of Muslims are distorted by social desirability. (This assumption is supported by the finding that, according to the results of the International Social Survey Programme 2008, Turks living in Turkey reject interreligious marriages much more frequently than Turkish migrants living in Austria.)

The four aspects of religiosity and attitudes to religion addressed in hypotheses 1 to 4 were operationalized in the following way:

- (Church-related) Religiosity: The questionnaire includes a number of questions on respondents' religious beliefs and attitudes to religion. An exploratory factor analysis shows that five items are especially well suited to measure individual religiosity: frequency of attending religious service, frequency of prayer, frequency of participating in activities of a religious community, belief in a personal God ("There is a God who concerns himself with every human being personally") and subjective religiosity. Cronbach's alpha for the scale of these items is 0.87 .

- Evaluation of the role of religion in society is measured by a scale consisting of the following four items: "Looking around the world, religions bring more conflicts than peace", "People with strong religious beliefs are intolerant to others", "The churches in Austria have too much power" and "Religion represents the past and not the future" (Cronbach's alpha=0.56). 
Table 3 Correlation between the four dimensions of religious attitudes

\begin{tabular}{lllll}
\hline & Religiosity & Spirituality & $\begin{array}{l}\text { Evaluation of } \\
\text { religion }\end{array}$ & $\begin{array}{l}\text { Sexual } \\
\text { morality }\end{array}$ \\
\hline Religiosity (high-low) & 1.00 & 0.09 & 0.50 & 0.32 \\
$\begin{array}{l}\text { Spirituality (high-low) } \\
\begin{array}{l}\text { Evaluation of religion (posi- } \\
\text { tive-negative) }\end{array}\end{array}$ & 0.09 & 1.00 & 0.01 & -0.10 \\
$\begin{array}{l}\text { Sexual morality (restric- } \\
\text { tive-permissive) }\end{array}$ & 0.30 & 0.01 & 1.00 & 0.31 \\
\hline
\end{tabular}

- Sexual morality: As mentioned above, the survey does not include items that ask for fundamentalist religious attitudes directly. However, respondents were asked about their attitudes towards "premarital sex", "homosexual relationships" and "abortion". Since a strict sexual morality is an important component of Christian and Muslim fundamentalism, the scale of these three items was used as a proxy for religious fundamentalism (Cronbach's alpha=0.58).

- Spirituality: The questionnaire includes six items asking for personal experience with spiritual, esoteric and complementary health methods. An exploratory factor analysis of these items yields two factors: The first is characterized by high loadings on four items that refer to body-mind-spirit practices ("meditation", "yoga and related methods", "complementary medicine" and "reading books on spiritual or esoteric topics"); the second factor is composed of two items that refer to magical-esoteric practices ("faith healing" and "astrology or fortune telling"). Bivariate analyses show that the factor-score of the first factor has a significant impact on the dependent variables (attitudes to religious others), while this is not the case for the second factor. Thus, only the four items with high loadings on the first factor will be used as measurement of spirituality for the following multivariate (Cronbach's alpha for this scale is 0.72).

The bivariate correlations presented in Table 3 show that religiosity and spirituality do not exclude each other mutually; there is even a weakly positive association between being religious and being spiritual. As one should expect, higher levels of religiosity go together with more positive evaluations of the role of religion in society $(r=0.50)$ and with a tendency to advocate strict sexual morality $(r=0.32)$.

\subsection{Multivariate analysis}

In the second part of the analysis, the impact of respondent's relationship with religion on their evaluation of religious others is examined by multiple linear regressions. Table 4 presents the results of four regressions concerning attitudes towards Muslims, Jews, Buddhists, and atheists or nonreligious people. The central independent variables are the four religious-attitude scales presented above (religiousness, 
Table 4 Determinants of attitudes to Muslims, Buddhists, Jews and atheists/nonbelievers (OLS regressions)

\begin{tabular}{|c|c|c|c|c|c|c|c|c|}
\hline & \multicolumn{2}{|c|}{ Muslims } & \multicolumn{2}{|l|}{ Jews } & \multicolumn{2}{|c|}{ Buddhists } & \multicolumn{2}{|c|}{$\begin{array}{l}\text { Atheists/ } \\
\text { nonbelievers }\end{array}$} \\
\hline & Beta & Sig & Beta & Sig & Beta & Sig & Beta & $\mathrm{Sig}$ \\
\hline \multicolumn{9}{|l|}{ Demographic variables } \\
\hline Sex (male-female) & -0.07 & $* * *$ & -0.04 & & -0.02 & & 0.06 & \\
\hline Age (young-old) & 0.03 & & -0.02 & & 0.00 & & 0.02 & \\
\hline Education (low-high) & -0.12 & $* * *$ & -0.08 & $* * *$ & -0.07 & $* *$ & -0.05 & $*$ \\
\hline Urban-rural & 0.02 & & 0.09 & $* * *$ & 0.06 & $* *$ & 0.02 & \\
\hline \multicolumn{9}{|l|}{ Attitudes to religion } \\
\hline Religiosity (high-low) & 0.05 & & 0.17 & $* * *$ & 0.14 & $* * *$ & -0.18 & $* * *$ \\
\hline Spirituality (high-low) & 0.09 & $* * *$ & 0.13 & $* * *$ & 0.20 & $* * *$ & 0.09 & $* * *$ \\
\hline $\begin{array}{l}\text { Evaluation of religion } \\
\text { (positive-negative) }\end{array}$ & 0.22 & $* * *$ & 0.09 & $* * *$ & 0.05 & & -0.06 & $*$ \\
\hline $\begin{array}{l}\text { Sexual morality } \\
\text { (restrictive-permissive) }\end{array}$ & -0.09 & $* * *$ & -0.08 & $* *$ & -0.09 & $* * *$ & -0.06 & $* *$ \\
\hline Muslim (yes-no) & 0.25 & $* * *$ & - & & & & & \\
\hline $\mathrm{R}^{2}$ & 0.173 & & 0.094 & & 0.093 & & 0.084 & \\
\hline$(N=)$ & (1185) & & (1185) & & $(1185)$ & & (1185) & \\
\hline
\end{tabular}

Coding of dependent variables: $1=$ positive attitudes; $5=$ negative attitudes

Significance levels: ***: $p \leq 0.01 ; * *: p \leq 0.05 ; *: p \leq 0.10$

evaluation of the role of religion in society, sexual morality and spirituality). ${ }^{2}$ In addition, the demographic variables sex, age, education and place of living (urbanrural) were included in the model; since these variables are relevant for my analysis only as control variables, their effect will not be discussed in detail.

It would have been worthwhile to include (dummy variables for) religious denomination into the regression-model. However, because of the high correlation between non-affiliation and not being religious, a serious problem of multicollinearity emerges. ${ }^{3}$ Thus, religious denomination was not included in the regression. For the regression concerning "attitudes to Muslims" the omission of "Muslim" from the list of independent variables leads to a considerable distortion of the results (because Muslims rate their own religion much more positively than the rest of the sample). Therefore, for this regression the dummy variable "Muslim" (versus NonMuslim) was included in the regression.

As we can see in Table 4, a rather similar pattern of results emerges for the evaluation of Muslims, Jews and Buddhists: religious respondents, spiritual respondents and those who consider religion as beneficial for society have more positive attitudes towards these three groups of religious others. Advocating a strict sexual morality is connected to more negative evaluations of religious others. There are,

\footnotetext{
2 The collinearity test shows, that the simultaneous inclusion of these variables in one regression model does not cause multicollinearity. The Variance Inflation Factor (VIF) for all four variables remains clearly below the critical value of 2.0.

3 VIF for religiosity is above the critical value of 2.0.
} 
however, some notable differences concerning the size of the effect: As expected, spirituality is strongly associated with a positive assessment of Buddhism. On the other hand, attitudes towards Muslims depend in particular on one's evaluation of the role of religion in society. Respondents who think that churches have too much power and perceive religions as a source of violence and intolerance reject Muslims significantly more strongly than others. For the evaluation of atheists and nonbelievers a somewhat different pattern emerges. Religious people have clearly more negative attitudes towards this group than the nonreligious. Advocating strict sexual morality and perceiving religion as beneficial for social life has an additional negative effect on the evaluation of atheists. In contrast, spirituality is connected to more positive evaluations of atheists and nonbelievers. As we have seen already from the descriptive statistics in Table 1, Muslims rate their own religious group much more positively than non-Muslims. This is the main reason why the proportion of explained variance $\left(\mathrm{R}^{2}\right)$ is significantly higher in the first regression (attitudes to Muslims) than in the other three regressions (attitudes to Jews, Buddhists, and to atheists or nonreligious people).

As a last step of the analysis, the six items on attitudes to Christians, Muslims, Jews, Hindus, Buddhists, and atheists/nonreligious were combined into a scale that measures attitudes towards religious others in general or, in other words, acceptance of religious diversity. For this purpose, the ratings of the five groups that respondents did not belong to were added up; e.g., the scale score for Christians corresponds to the sum of points for the five items: attitudes to Muslims, Jews, Hindus, Buddhists, and atheists/nonreligious. ${ }^{4}$ This scale was subjected to a multiple regression with the same independent variables as the regressions presented above. Furthermore, the same model of regression was carried out for the two items on interreligious relationships, i.e. respondents' attitudes to interreligious marriage and their opinions on whether people with different religions can get along well together or not. ${ }^{5}$

The three regressions in Table 5 show similar patterns of results for three of the four scales of religious attitudes. Spirituality has the strongest impact on attitudes to religious others. Spiritual persons rate religious others and interreligious relationships significantly more positively than respondents who do not have any experience with alternative spiritual methods. Also, positive evaluations of the role of religion in society and permissive sexual morals have a consistent positive impact on the attitudes to religious others. However, the effect of religiousness is different in the three regressions: Religious people more often report having a positive opinion of people belonging to other religions, but they are more skeptical about interreligious marriages and other forms of interreligious relations than the nonreligious.

Finally, I would like to briefly discuss the influence of demographic variables on attitudes towards religious others. In the regressions presented in Tables 4 and 5, more highly educated respondents, women, and people living in urban areas show up as somewhat more open to religious others than the less educated, men and

\footnotetext{
4 For respondents who do not belong to a religious denomination, the answers for attitudes towards the five religious groups (Christians, Muslims, Jews, Buddhists and Hindus) were combined into a scale.

5 The bivariate correlation between these two items is (only) 0.26 . Thus, it seems to be appropriate to analyze them separately.
} 
Table 5 Determinants of attitudes to religious diversity (OLS-Regressions)

\begin{tabular}{|c|c|c|c|c|c|c|}
\hline & \multicolumn{2}{|c|}{$\begin{array}{l}\text { Attitudes to reli- } \\
\text { gious others (posi- } \\
\text { tive-negative) }\end{array}$} & \multicolumn{2}{|c|}{$\begin{array}{l}\text { Attitudes to interreli- } \\
\text { gious marriage (posi- } \\
\text { tive-negative) }\end{array}$} & \multicolumn{2}{|c|}{$\begin{array}{l}\text { People who have different } \\
\text { religions do not get along well } \\
\text { together } \\
\text { (disagree-agree) }\end{array}$} \\
\hline & Beta & Sig & Beta & Sig & Beta & Sig \\
\hline \multicolumn{7}{|c|}{ Demographic variables } \\
\hline $\begin{array}{l}\text { Sex } \\
\text { (male-female) }\end{array}$ & -0.04 & $* * *$ & -0.06 & $* *$ & -0.08 & $* * *$ \\
\hline $\begin{array}{l}\text { Age } \\
\text { (low-high) }\end{array}$ & 0.00 & & 0.00 & & -0.04 & \\
\hline $\begin{array}{l}\text { Education } \\
\text { (low-high) }\end{array}$ & -0.10 & $* * *$ & -0.12 & $* * *$ & -0.13 & $* * *$ \\
\hline Urban-rural & 0.06 & $*$ & 0.01 & & 0.09 & $* * *$ \\
\hline \multicolumn{7}{|c|}{ Attitudes to religion } \\
\hline $\begin{array}{l}\text { Religiosity } \\
\text { (high-low) }\end{array}$ & 0.09 & $* *$ & -0.12 & $* * *$ & 0.02 & \\
\hline $\begin{array}{l}\text { Spirituality } \\
\text { (high-low) }\end{array}$ & 0.16 & $* * *$ & 0.16 & $* * *$ & 0.19 & $* * *$ \\
\hline $\begin{array}{l}\text { Evaluation of } \\
\text { religion } \\
\text { (positive-negati }\end{array}$ & 0.11 & $* * *$ & 0.03 & & 0.14 & $* * *$ \\
\hline $\begin{array}{l}\text { Sexual } \\
\text { morality } \\
\text { (restrictive-peri }\end{array}$ & $\begin{array}{l}-0.11 \\
\text { issive) }\end{array}$ & $* * *$ & -0.13 & & -0.11 & $* * *$ \\
\hline $\mathrm{R}^{2}$ & 0.090 & & 0.093 & & 0.130 & \\
\hline$(N=)$ & $(1185)$ & & (1106) & & (1145) & \\
\hline
\end{tabular}

Significance levels: ***: $p \leq 0.01 ; * *: p \leq 0.05 ; *: p \leq 0.10$

people living in rural areas. Among these three variables, education has clearly the strongest impact. This is in line with a large number of studies that have found a positive connection between higher education and tolerance towards different types of social minorities (e. g Hjerm 2001; Rippl 2002; Thalhammer et al. 2001; Pollack 2014 b). Somewhat surprisingly, there is almost no difference between younger and older people in regard to the acceptance of religious others. Stepwise hierarchical regressions show that the four demographic variables explain no more than two to three percent of the total variation of the dependent variables in Tables 4 and 5 . Also, the impact of the four dimensions of religious attitudes is not very strong, but their explanatory power is considerably higher than that of the demographic variables in the model $\left(\mathrm{R}^{2}\right.$ for the four religious scales is between 0.07 and 0.10 for the individual regressions).

\section{Conclusion}

In modern Western societies, free choice of one's religious orientation is a fundamental civil right. Ensuring free choice and exercise of religion not only requires legal guarantees and institutional regulations, it also requires that people accept or 
at least tolerate the religious and ideological convictions of their fellow-citizens and the codes of behavior related to these convictions. In this article I have investigated to what extent the acceptance of religious others depends on people's own religious orientations. Four aspects were hypothesized to be relevant in this this context. (1) Respondent's religiosity, that is, to what extent they are religious believers, practice religion and participate in the activities of a religious community, (2) respondent's spirituality, i.e. their affinity to alternative spiritual and holistic practices, (3) respondent's affinity to fundamentalist religious positions, and (4) their evaluation of the role of religion in society.

My empirical analyses of the Austrian Social Survey 2018 show that spirituality is the strongest predictor of acceptance of religious diversity and positive attitudes towards interreligious relationships. This corresponds to the descriptions of the alternative spiritual milieu in the literature: Spiritual seekers assume that the same basic truths can be found in all religions and thus have an undogmatic, inclusive approach towards other religions (Heelas and Woodhead 2007; Wuthnow 2005; Bochinger et al. 2009). According to the findings presented in this paper the openness of spiritual seekers to religious others extends to atheists and nonreligious persons as well.

People who are close to "sectarian", dogmatic-authoritarian and fundamentalist religious positions represent the opposite pole. Due to the lack of more comprehensive data, religious fundamentalism had to be measured via the dimension of (rigid) sexual morality, which is an important component of religious fundamentalism. Sexual rigorism is also one of the subdimensions of Adorno's concept of the "authoritarian personality" (Adorno et al. 1950) which presumably can also be applied to religious fundamentalism. The empirical analyses presented in this paper confirm that respondents advocating strict sexual morals reject different categories of religious others as well as atheists and nonreligious people significantly more frequently than respondents characterized by a permissive sexual morality.

A third factor that contributes to the explanation of people's attitudes to religious others is their evaluation of the role of religion in society. Respondents who think that religion has a beneficial impact on society have more positive attitudes to religious diversity and to interreligious relationships than those who think that religions bring more violence than peace, that religious people are intolerant towards others and that religious institutions have too much power in our society. Accordingly, the latter have more sympathy for atheists and nonreligious people than the former. The impact of a respondent's religiosity points in the same direction. People who practice religion and participate in the activities of a religious community have more sympathy for people belonging to other (world) religions, and a stronger tendency to reject atheists than nonreligious people. The attitudes of religious persons towards religious diversity are more ambivalent and skeptical, however, when it comes to the question of interfaith marriage and interreligious relationships.

Furthermore, the findings of my analysis indicate that attitudes to religious others depend upon one's religious denomination, more precisely, on the position of one's religion in the religious field of the respective society. In the case of Austria this means that persons belonging to religious minorities, i.e. (Lutheran) Protestants, Orthodox Christians and Muslims, are more open to religious others and to interre- 
ligious relationships than persons belonging to the religious majority of Catholics. However, it should be emphasized again that the assessment of religious others, both on the part of religious minorities and on the part of the religious majority, may be biased due to the tendency of (some) respondents to give socially desirable answers.

Finally, the results of the Austrian Social Survey show a clear rank-order of how members of different world religions are rated: Christians are rated most positively, which is obviously due to the fact that the majority of respondents are Christians. Among the other four world religions, Buddhists are rated most favorably, while Muslims are clearly the worst rated group. This rank-order seems to reflect the public perception of Buddhism as a peaceful and undogmatic religion, in contrast to Islam, which is often perceived as fundamentalist, intolerant and aggressive.

When looking at the contemporary religious field in Austria, there are two main religious-ideological conflict lines. The first is the tension between fundamentalist Christians and Muslims. Since (Christian) fundamentalism is not very common in Austria, this type of conflict is less important. The second field of tension is that between non-religiosity and traditional forms of religion that are perceived as "fundamentalist" on part of the nonreligious. This type of conflict is much more salient; it became visible in a drastic way in the controversies about the Danish Mohammed cartoons and the terrorist attack on the makers of the French satirical magazine Charlie Hebdo. With reference to the right of free speech, European cartoonists to whom religion means nothing consider it legitimate to criticize the social behavior of religious groups up to the point of ridiculing their sacred symbols and beliefs. Devout Muslims, in turn, have no understanding for such kind of humor and consider it legitimate that such kind of sacrilege deserves severe punishment (Ata 2011; Gottschalk and Greenberg 2008).

Summing up the results, one can say that the majority of Austrians accept or at least tolerate people belonging to other religions as long as these groups do not stand out in public space and as long as their beliefs and ethical principles are adapted to the prevailing worldviews and the common ways of life in modern Western societies. However, for many people living in the highly secularized European societies it is difficult to tolerate religions that question the modern scientific worldview (e.g. by rejecting the theory of evolution), and promote ethical principles and codes of conduct that the secularized majority considers as harmful, as is the case for example with the Islamic dress codes for females. In the current socio-religious constellation in Austria as well as in other European countries, the principle of religious freedom on the one hand, and the demands on religious minorities to accept the basic principles of modern secularized society, are in conflict with each other. A successful integration of (ethno-)religious minorities into our society will only be possible if both sides take steps to reconcile these conflicting principles.

Acknowledgements I would like to thank Martin Weichbold and the anonymous reviewers for their helpful comments on preliminary versions of this article.

Funding Open access funding provided by University of Graz.

Open Access This article is licensed under a Creative Commons Attribution 4.0 International License, which permits use, sharing, adaptation, distribution and reproduction in any medium or format, as long as you give appropriate credit to the original author(s) and the source, provide a link to the Creative Com- 
mons licence, and indicate if changes were made. The images or other third party material in this article are included in the article's Creative Commons licence, unless indicated otherwise in a credit line to the material. If material is not included in the article's Creative Commons licence and your intended use is not permitted by statutory regulation or exceeds the permitted use, you will need to obtain permission directly from the copyright holder. To view a copy of this licence, visit http://creativecommons.org/licenses/by/4.0/.

\section{References}

Adorno, Theodor W., Else Frenkel-Brunswik, Daniel Levinson, and Nevitt Sanford. 1950. The authoritarian personality. New York: Harper and Row.

Assmann, Jan. 2009. The mosaic distinction or the price of monotheism. Stanford: Stanford University Press.

Ata, Mehmet. 2011. Der Mohammed-Karikaturenstreit in den deutschen und türkischen Medien. Eine vergleichende Diskursanalyse. Wiesbaden: VS.

Barnett, S.J. 2003. The enlightenment and religion. The myths of modernity. Manchester: Manchester University Press.

Bochinger, Christoph, Martin Engelbrecht, and Winfried Gebhard. 2009. Die unsichtbare Religion in der sichtbaren Religion: Formen spiritueller Orientierung in der religiösen Gegenwartskultur. Stuttgart: Kohlhammer.

Brahm Levey, Geoffrey. 2008. Secularization and religion in a multicultural age. In Secularization, religion and multicultural citizenship, ed. Geoffrey Brahm Levey, Tariq Modood, 1-24. Cambridge: Cambridge University Press.

Christiano, Kevin J. 2017. European principles and Canadian practices: developing secular contexts for religious diversity. In Multireligious society. Dealing with religious diversity in theory and practice, ed. Francisco Colom Gonzalez, Gianni D’Amato, 45-62. London: Routledge.

Clark, Christopher, and Wolfram Kaiser. 2002. Kulturkampf in Europa im 19. Jahrhundert. Comparativ. Zeitschrift für Globalgeschichte und vergleichende Gesellschaftsforschung 5-6:7-13.

Dawson, Lorne. 2006. Comprehending cults: the sociology of new religious movements. Oxford: Oxford University Press.

Friedrichs, Nils. 2014. Das Verhältnis von Christen zu Muslimen und Atheisten: Zur Bedeutung von sozialer Kategorisierung und Identifikation im interreligiösen Vergleich. In Grenzen der Toleranz. Wahrnehmung und Akzeptanz religiöser Vielfalt in Europa, ed. Detlef Pollack, Olaf Müller, Gergely Rosta, Nils Friedrichs, and Alexander Yendell, 155-178. Wiesbaden: VS.

Gottschalk, Peter, and Gabriel Greenberg. 2008. Islamophobia. Making muslims the enemy. Plymouth: Rowman \& Littlefield.

Goujon, Anne, Sandra Jurasszovich, and Michaela Potančoková. 2017. Demographie und Religion in Österreich. Szenarien 2016 bis 2046. Vienna: ÖIF.

Heelas, Paul, and Linda Woodhead. 2007. The spiritual revolution. Why religion is giving way to spirituality. Oxford: Blackwell.

Hjerm, Mikael. 2001. Education, xenophobia and nationalism: A comparative analysis. Journal of Education and Migrant Studies 27(1):37-60.

Höllinger, Franz. 2013. Trends in church attendance among Christian societies in the second half of the $20^{\text {th }}$ century. In ISSP data report. Religious attitudes and religious change Schriftenreihe, Vol. 13, ed. Insa Bechert, Markus Quandt, 47-59. Köln: Gesis Leibiz-Institut für Sozialwissenschaften.

Höllinger, Franz, and Thomas Tripold. 2012. Ganzheitliches Leben. Das holistische Milieu zwischen neuer Spiritualität und postmoderner Wellness-Kultur. Bielefeld: transcript.

Houtman, Dick, and Stef Aupers. 2007. The spiritual turn and the decline of tradition: the spread of postChristian spirituality in 14 western countries, 1981-2000. Journal for the Scientific Study of Religion 46(2):305-320.

Kalmijn, Matthijs, and Frank van Tubergen. 2006. Ethnic intermarriage in the Netherlands: Confirmations and refutations of accepted insights. European Journal of Population 22(4):371-397.

Kalter, Frank, and Julia Schroedter. 2010. Transnational marriage among former labour migrants in Germany. Zeitschrift für Familienforschung 22(1):11-32.

Kettell, Steven. 2019. Secularism and religion. In Oxford research encyclopedia. Politics, 1-16. Oxford: Oxford University Press. https://doi.org/10.1093/acrefore/9780190228637.013.89.

Knoblauch, Hubert. 1999. Religionssoziologie. Berlin: De Gruyter. 
Modood, Tariq, and Riva Kastoryano. 2006. Secularism and the accommodation of muslim identities. In Multiculturalism, muslims and citizenship. A European approach, ed. Anna Triandafyllidou, Tariq Modood, and Ricard Zapata-Barrero, 162-178. London, New York: Routledge.

Nexon, Daniel H. 2009. The struggle for power in early modern europe: religious conflict, dynastic empires, and international change. Princeton: Princeton University Press.

Pollack, Detlef. 2014a. Wahrnehmung und Akzeptanz religiöser Vielfalt in ausgewählten Ländern Europas. In Grenzen der Toleranz. Wahrnehmung und Akzeptanz religiöser Vielfalt in Europa, ed. Detlef Pollack, Olaf Müller, Gergely Rosta, Nils Friedrichs, and Alexander Yendell, 13-34. Wiesbaden: VS.

Pollack, Detlef. 2014b. Grenzen der Toleranz: Deutschlands Plädoyer für die Ungleichbehandlung von Religionsgemeinschaften. In Grenzen der Toleranz. Wahrnehmung und Akzeptanz religiöser Vielfalt in Europa, ed. Detlef Pollack, Olaf Müller, Gergely Rosta, Nils Friedrichs, and Alexander Yendell, 35-46. Wiesbaden: VS.

Putnam, Robert. 2010. American grace: how religion divides and unites us. New York: Simon \& Schuster.

Rippl, Susanne. 2002. Bildung und Fremdenfeindlichkeit. Die Rolle schulischer und familialer Sozialisation zur Erklärung von Bildungsunterschieden im Ausmaß von fremdenfeindlichen Einstellungen. Kölner Zeitschrift für Soziologie und Sozialpsychologie 54(1):135-146.

Schneiders, Thorsten G. (ed.). 2010. Islamfeindlichkeit. Wenn die Grenzen der Kritik verschwimmen. Wiesbaden: VS.

Singer, Margareth. 2002. The process of brainwashing, psychological coercion and thought-reform. In Cults and new religious movements, ed. Lorne Dawson, 147-159. Malden, Oxford: Blackwell.

Stolz, Jörg, Judith Könemann, Mallory Schneuwly Purdie, Thomas Englberger, and Michael Krüggeler. 2014. Religion und Spiritualität in der Ich-Gesellschaft: Vier Gestalten des (Un-)Glaubens. Zürich: Edition NZN.

Taylor, Charles. 2007. A secular age. Harvard: Harvard University Press.

Thalhammer, Eva, Vlasta Zucha, Edith Enzenhofer, Brigitte Salfinger, and Günther Ogris. 2001. Attitudes towards minority groups in the European Union. http://www.fudepa.org/Biblioteca/recursos/ficheros/ BMI20060000083/attitudes.pdf. Accessed 10 Mar 2020. SORA-Institut, Vienna.

Triandafyllidou, Anna. 2011. Addressing cultural, ethnic \& religious diversity challenges in Europe. A comparative overview of 15 European countries. http://cadmus.eui.eu/bitstream/handle/1814/19254/ ACCEPT_PLURALISM_2011-02_WP1_ComparativeReport_rev.pdf?sequence=5\&isAllowed=y;. Accessed 10 Mar 2020. European University Institute, Florence.

Wuthnow, Robert. 2005. America and the challenges of religious diversity. Princeton: Princeton University Press.

Zulehner, Paul, and Regina Polak. 2009. Von der „Wiederkehr der Religion“ zur fragilen Pluralität. In Die Österreicher/-innen. Wertewandel 1990-2008, ed. Christian Friesl, Regina Polak, and Ursula Hamachers-Zuba, 143-206. Wien: Cernin Verlag.

Franz Höllinger is Associate Professor at the Department of Sociology at the University of Graz. His main research areas are sociology of religion and alternative spiritualities, sociology of the family and cross-national-comparative survey research. 